\title{
THE EFFECT OF JOB SATISFACTION ON ORGANIZATIONAL COMMITMENT AND WORK DISCIPLINE: A STUDY OF FOUNDATION PERMANENT LECTURERS IN STIE YAPAN SURABAYA
}

\author{
Winarsih Tutik \\ STIE YAPAN Surabaya, Indonesia \\ E-mail: twinarsih@stieyapan.ac.id
}

\begin{abstract}
This research aimed to examine the effect of job satisfaction on organizational commitment and work discipline, and the effect of organizational commitment on work discipline. This research involved active foundation permanent lecturers in STIE (School of Economics) YAPAN Surabaya. The data analysis technique used was path analysis and confirmatory factor analysis to confirm the indicators explaining the construct or variable. Confirmatory factor analysis results proved that all indicators of each variable were able to explain the variables of job satisfaction, organizational commitment and work discipline. The results of path analysis indicate that job satisfaction influenced organizational commitment, organizational commitment influenced discipline, and job satisfaction influenced work discipline. The results of this research support the theory that the more satisfied employees are, the more committed and disciplined they are in carrying out their duties. The practical implications of this research are expected to be taken into consideration for the foundation in terms of making policies and decisions related to job satisfaction, organizational commitment, and work discipline. The foundation is suggested to pay more attention to the dimensions of salaries, normative commitment, and work discipline because these dimensions are perceived poorly.
\end{abstract}

\section{KEY WORDS}

Job satisfaction, organizational commitment, work discipline, policy.

There have been many theories of job satisfaction discussed in previous studies. One well-known theory is a two-factor theory by Herzberg. In Furnham et al. (2009), the two-factor theory is a theory of job satisfaction suggesting that satisfaction and dissatisfaction are part of a different group of variables, namely motivators and hygiene factors. Many impacts will arise if a person is satisfied with his workplace, one of which is on his organizational commitment. Gunlu et al. (2009) found a positive relationship between job satisfaction and organizational commitment. Naderi (2011) also found a significant positive correlation between job satisfaction and organizational commitment. Similarly, according to Silva (2006), a significant relationship exists between job satisfaction and organizational commitment. When someone's job satisfaction increases, his organizational commitment will automatically increase as well.

Besides influencing organizational commitment, job satisfaction also affects work discipline. Lange (2008) discovered that discipline, attitudes, values and beliefs of employees indicate perceived satisfaction. The more an employee feels satisfied, his discipline, attitudes, values, and beliefs will get better. According to a study conducted by Maryadi (2012), job satisfaction has a significant effect on work discipline. A satisfied person will reflect positive attitudes towards his work, stimulating high work discipline.

There are several factors influencing discipline in addition to job satisfaction, one of which is organizational commitment. Haarr (1997) proved that in organizations and working fields, e.g. police, organizational commitment is a mediating variable to explain the disciplinary behavior of officers (policemen) while on patrol. Gilder (2003) in his study revealed that someone who has long been committed in a workplace will have better discipline than those who are just starting committed to the workplace. Chan (2006) found that high commitment from group members will energize and motivate them to work better. 
Highly committed members will accept each other, learn from other members, and participate fully in all organizational activities. They will create their norms to deal with other members who are not disciplined, such as what to do if members do not attend meetings or how to deal with absent members.

STIE (School of Economics) YAPAN is a private higher education institution. STIE YAPAN is part of Palapa Nusantara Foundation providing three study programs, namely Management, Accounting, and Master of Management, all of which are B-Accredited. Based on the results of interviews with 30 foundation lecturers in YAPAN School of Economics, information about the foundation lecturers' complaints were obtained. The most often complained things were the work environment and compensation.

The interview results showed that $57 \%$ of the foundation lecturers complained about the unfavorable work environment, the other $33 \%$ considered that the work environment was quite good, and the rest $10 \%$ thought well of the work environment. The work environment aspect that did not meet the expectations of the foundation lecturers was caused by the lack of availability of supporting tools for teaching and learning activities such as LCDs. Not all lecturers got LCDs due to the limited number. Additionally, some LCDs were damaged so that they could not be used.

Besides the work environment, another thing that was often complained by the foundation lecturers was compensation, where $53 \%$ of the lecturers complained that the compensation was not good, the other $27 \%$ thought that it was quite good, while the rest $20 \%$ thought well of the compensation. The most commonly complained aspect is the lack of increase in compensation. Foundation lecturers in STIE YAPAN expect an increase in compensation in line with the increasingly expensive life needs. They also want the provision of health benefits.

From the data, it can also be learned that the foundation lecturers in STIE YAPAN felt dissatisfied with both the work environment and compensation. Tranggono and Kartika (2008) stated that joy felt by someone has a positive impact on him. If someone is satisfied with the job he is undertaking, joy will come regardless of feeling depressed, causing a sense of security and comfort to always work in his work environment. Furthermore, based on the direct observation results, despite through invitations for meetings or other activities, not all foundation lecturers fulfilled the invitation and they even seemed reluctant to attend with various reasons or even without any reasons. Only a few lecturers joined the invitations. Some even only filled in the attendance list.

According to the results of interviews with 30 foundation lecturers in the environment of STIE YAPAN, it was known that $60 \%$ of the foundation lecturers would receive offers of teaching jobs elsewhere if any while the rest $40 \%$ refused such offers. Other data showed that $57 \%$ of the foundation lecturers in the environment of STIE YAPAN also taught in other places while the rest $43 \%$ only taught in the environment of STIE YAPAN. Cotton and Tutle in Wei Amy (2009) stated that employees who are dissatisfied with their jobs or not committed to their organization are likely to leave the company.

Based on the background of the problems raised above, the statements of problem or aims of this research were to test and analyze whether job satisfaction has a significant direct effect on organizational commitment; whether job satisfaction has a significant direct effect on work discipline; and whether organizational commitment has a significant direct effect on work discipline.

\section{LITERATURE REVIEW}

According to Siagian (2003), discipline is a managerial action for encouraging organization members to meet the demands of various provisions to be complied with. Simamora (2005) explained that discipline is a procedure correcting or punishing subordinates for violating rules or procedures. Handoko (2010) defined discipline as a managerial activity to run organizational standards. Meanwhile, Rollinson (2000) stated that discipline is some actions taken against an individual who fails to adjust to organizational rules. 
Based on some opinions above, it can be concluded that a discipline is a form of one's great responsibility for a task given by the leader of the company and also can be interpreted as providing strict action for employees who do not comply with company rules.

According to Simamora (2005), communication can influence work discipline. Communication is a source of organizational problems. Failure in communicating adequate work standards and expectations is one of the triggers for discipline, therefore communication affects employee work discipline. According to Haarr (1997), organizational commitment is a mediating variable to explain the disciplinary behavior of officers (policemen) while on patrol. Officers with low work commitment will tend to manipulate their duties in providing services to society and take deviant actions from their obligations. In contrast, officers with high work commitment will carry out their duties properly according to their responsibilities without any manipulation. According to Sukirman (2011), there is a significant positive relationship between job satisfaction and work discipline of employees. High disciplined employees are stimulated by the feeling of liking their jobs and workplaces. Less satisfied employees in working can lead to inadequate working conditions, lack of achievement opportunities, and lack of recognition from superiors. The lower job satisfaction felt by employees can result in the weaker discipline of working.

Sutrisno (2009) stated that job satisfaction is an attitude of employees towards their jobs concerning work situations, cooperation between employees, the benefits received at work, and other physical and psychological factors. This attitude towards jobs is the result of some individual special attitudes and social relationships outside the individual work so that it raises the general attitude of the individual towards the job carried out. Bhuian and Menguc in James Boles et al. (2007) defined job satisfaction as an individual attitude or sense of belonging towards his job. It refers to the extent to which someone feels positive or negative about the intrinsic and/ or extrinsic aspect of a job.

Prabu (2005) stated that job satisfaction is the difference between the expectation imagined by someone from the contribution of work that has been done and the reality hoped. From several opinions above, it can be concluded that job satisfaction is someone's response to what they expect when working and what they get after they do the job.

Job satisfaction is related to work situations, cooperation between employees, benefits, and other factors. If there is a small difference between what a person expects and achieves, he will be satisfied and vice versa.

The theory of job satisfaction tries to reveal what makes some people more satisfied with their jobs than some others. This theory also seeks a basis for the process of people's feelings towards job satisfaction. In this research, the theory used was the two-factor theory by Herzberg. Furnham et al. (2009) revealed that a theory of job satisfaction suggesting that satisfaction and dissatisfaction are part of a different group of variables, namely motivators and hygiene factors. In general, people are satisfied when certain factors are available and dissatisfied when they are not available. Based on this theory, dissatisfaction is associated with the surrounding conditions and not with the job itself because this factor prevents negative reactions, called hygiene or maintenance factors.

On another side, satisfaction derives from factors concerning the job itself or the direct results of thereof, promotion and opportunities for self-development and recognition because these factors are related to the high level of job satisfaction, called motivators.

A study entitled "Personality, motivation, and job satisfaction: Herzberg meets the Big Five" conducted by Furnham et al. (2009) examined the extent to which motivators and hygiene factors can explain variance in job satisfaction as defined in Herzberg's two-factor theory. The results of the research showed that motivators and hygiene factors are prerequisites for job satisfaction.

According to Mathis and Jackson in Sopiah (2008), organizational commitment is the extent to which employees believe in and accept organizational goals and desire to remain with the organization. In other words, organizational commitment is the extent to which employees believe and accept organizational goals and will remain or will not leave the organization. Swailes in James Boles et al. (2007) explained that organizational commitment reflects positive feelings towards the organization and its values. The measurement of 
organizational commitment is an assessment of the suitability between individual and organizational values or beliefs.

Based on different understandings of organizational commitment obtained from several experts above, there is a similarity that organizational commitment refers to a loyalty and trust someone has towards the organization. That is, organizational commitment describes the relationship between individuals and organizations. If individuals have a high organizational commitment, they will have loyalty and trust in the organization where they work.

\section{METHODS OF RESEARCH}

Based on the stated objectives, this research used was an explanatory research design. Explanatory research is research explaining the causal relationship between variables through the submission of hypotheses using the same data. This research used an explanatory research design to explain the causal relationship or the effect of job satisfaction on organizational commitment and work discipline by testing the hypotheses mentioned above.

Meanwhile, the method used was a descriptive survey method, which is a research method that takes a sample from a population and uses a questionnaire as a data collection tool. In this research, data and information were collected from respondents using a questionnaire. After data collection, the results were presented descriptively and, at the end of this research, were analyzed to test the hypotheses formulated at the beginning of this research (Effendi, 2003).

Sugiyono (1997) defined that population is the area of generalization consisting of objects or subjects which become the quantity and characteristics determined by researchers to be studied and concluded. Meanwhile, the sample is part of the quantity and characteristics possessed by the population. In this research, the population covered 30 people and the sampling technique used was saturated or census sampling, meaning that all active permanent foundation lecturers in STIE YAPAN Surabaya were used as samples/ respondents.

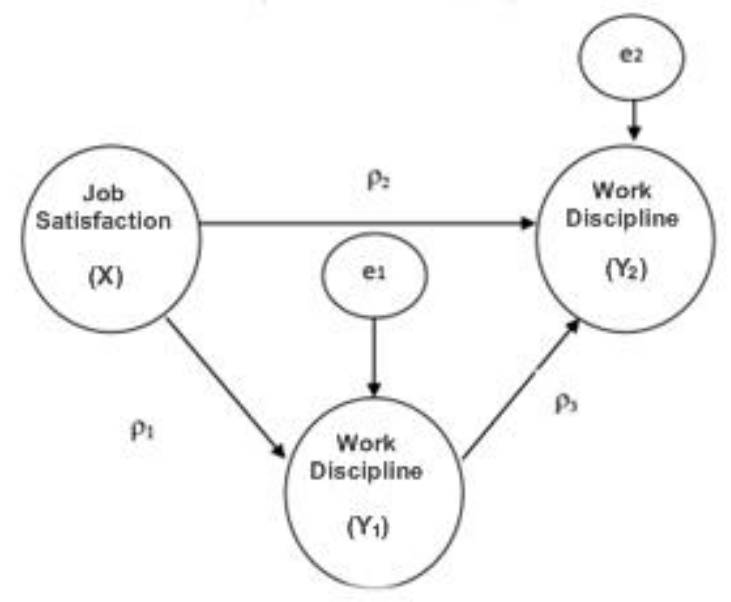

Figure 1 - Path Analysis Model

Data in the field were collected using these following tools:

- Questionnaire: Questionnaires were distributed to all foundation lecturers in STIE YAPAN Surabaya. Respondents answered the questionnaires without the intervention of the researchers;

- Interview: Interviews are used to gather information by holding question and answer sessions with related parties. Interviews in this research aimed to obtain additional information such as complains and opinions of foundation lecturers. 
Path analysis is used to analyze the relationship between variables to know direct and indirect effects, a set of independent (exogenous) variables on the dependent (endogenous) variable.

Path analysis is a pattern of causal relationships or a set of hypothesized causal asymmetric relation among variables (Riduwan and Engkos, 2010). As stated by Sugiyono (2010), the causal model of exogenous and endogenous variables is distinguished. The variables in path analysis are exogenous variables (causative variables) and endogenous variables (effect variables). as follows:

The steps carried out in the path analysis according to Riduwan and Engkos (2010) are

- Formulating hypotheses based on previous concepts and studies, that: Job Satisfaction has a direct positive effect on Organizational Commitment, Job Satisfaction has a direct positive effect on Work Discipline, and Organizational Commitment has a direct positive effect on Work Discipline;

- Determining sub-structures and drawing a complete path diagram according to the hypothesis proposed. Relationships between variables can be inserted into structural equations as seen in Formula 1 and 2, and Path Analysis Model Figure;

- Calculating the path coefficient through partial regression analysis where the path coefficient is standardized regression coefficients $(\beta)$ for the direct effects while the indirect effect is the multiplication of coefficient of the path passed through by each equation. The total effect is the sum of all direct and indirect effects;

- Checking the model validity to know the quality of an analysis result depending on the underlying assumptions. The indicators contained in the path analysis are total determination coefficients and theory trimming. Total Determination Coefficient is an indicator of model validity that has the same interpretation with determination coefficient in regression analysis;

- Interpreting path analysis results. Based on the results of the path analysis calculation, we can provide information about job satisfaction and its effect on organizational commitment and work discipline.

\section{RESULTS AND DISCUSSION}

The results of data analysis showed that the job satisfaction variable had a positive and significant effect on organizational commitment, identified from the coefficient value of the job satisfaction variable of 0.415 . Job satisfaction was measured using the indicators of satisfaction with the job itself, salary, supervision, promotion, and work relations. Based on the results of the lecturer assessment, the jobs given to the lecturers are in accordance with their fields of expertise; the lecturers are given the opportunity to develop their self-potentials in STIE; and the family relationships among lecturers can improve job satisfaction so that the lecturers feel better staying in the organization to carry out their careers. In line with these results, Naderi (2011) found a positive and significant relationship between job satisfaction and organizational commitment. Various dimensions of job satisfaction, such as the satisfaction with salary, satisfaction with coworkers, satisfaction with superior supervision, and satisfaction with the job itself, are needed by coworkers to meet their basic needs. When their needs are met, their organizational commitment level will also be high.

The results of data analysis also proved the positive and significant relationship between job satisfaction and work discipline, indicated by the coefficient value from the job satisfaction variable of 0.337 . When the lecturers are satisfied with various things, such as the job itself, salary, supervision, promotion and work relations, they will have a good attitude towards their jobs, be on time in teaching, and ready to accept sanctions when violating. In other words, the higher the lecturer's job satisfaction is, the higher his work discipline will be. Conversely, the lower the lecturer's job satisfaction is, the lower his work discipline will be. The condition that lecturers feel satisfaction for what they have done for STIE, this will have an impact on their discipline. Lecturers will be more disciplined in terms of both time and work. 
Organizational commitment consists of three dimensions, namely affective, sustainable and normative commitment. The results of the data analysis proved that the organizational commitment variable had a positive and significant effect on work discipline, indicated by the coefficient value of the organizational commitment variable of 0.250 . The commitment was measured using affective commitment, ongoing commitment, and normative commitment. The results suggest that the lecturers feel contented to spend their careers in STIE and find it difficult to quit STIE. This positive effect of loyalty can increase lecturer commitment so that they will be disciplined with all the rules applied in STIE. These results are consistent with Chan (2006) finding that high commitment of group members will energize and motivate them to work better. They will create their norms to deal with other members who are not disciplined. Lecturers with low commitment will manipulate their duties and obligations, tending to take deviating actions from their duties. Conversely, highly committed lecturers will carry out their duties accordingly to their responsibilities without any manipulation.

This research found that job satisfaction has a positive effect on organizational commitment, organizational commitment has a positive effect on work discipline, and job satisfaction has a positive effect on work discipline. The findings of this research enrich the empirical evidence of the effect of job satisfaction on organizational commitment and work discipline and the effect of organizational commitment on work discipline. The results of this research support the theory that when lecturers feel satisfied with their job, salary, supervision, promotion and relation with fellow lecturers, they will be committed to STIE. The more the lecturer feels satisfied, the more committed and disciplined the lecturer will be.

Based on the results of data analysis, lecturer work discipline is influenced by job satisfaction and organizational commitment. The results of the lecturer assessment related to job satisfaction, organizational commitment, and work discipline are still considered lowvalued so that more attention from the foundation is needed. Things to be considered by the foundation to increase job satisfaction include salaries and benefits still deemed insufficient and not in accordance with the responsibilities; leaders who still rarely give praise or recognition to lecturers for the results of work that has been done; low application of regulations by the leaders; and fewer opportunities to occupy different positions.

To increase organizational commitment, the foundation needs to consider the fact that the decision of lecturers to resign does not bring much disturbance in the organization and there are only a few lecturers who feel better to stay in one the organization for spending their careers. Meanwhile, things to be considered by the foundation to increase work discipline are the inconsistency of sanction imposition for violating lecturers and the lecturers' lack of reluctance to commit violations.

\section{CONCLUSION AND SUGGESTIONS}

From the results of data analysis in this research, it can be concluded that: Job Satisfaction is positively correlated with organizational commitment. The positive correlation means that the more lecturers feel satisfied with their jobs, the more committed they will be to STIE YAPAN Surabaya. Job satisfaction is also positively correlated with work discipline. This proves that the more lecturers feel satisfied with their jobs, the more disciplined they will be in carrying out their duties and responsibilities. Organizational commitment is positively correlated with work discipline. This can be interpreted that when lecturers are committed to STIE YAPAN Surabaya, they will be more disciplined.

Based on the conclusions explained above, the suggestions that can be given are: the foundation needs to pay more attention to job satisfaction and organizational commitment of lecturers to improve the work discipline of permanent foundation lecturers in STIE YAPAN Surabaya. The lecturers' job satisfaction is generally good. However, in an effort to improve work discipline, the foundation needs to increase salaries and benefits deemed insufficient and not in accordance with the responsibilities, instruct leaders to more frequently praise and appreciate (give recognition) for the results of work that has been done, establish firmly the application of regulations by the leaders, and give more opportunities to occupy different positions. Meanwhile, good-valued things such as the suitability of the jobs given with the 
fields of expertise, the opportunity to develop the lecturers' potentials in STIE, and the establishment of family relationships among fellow lecturers must be maintained by the foundation.

The lecturers' organizational commitment in general also has a good value. However, there are still some low-valued things needed to improve by the foundation, including the insignificant impact or disturbance caused by the decision of lecturers to resign from the organization and the small number of lecturers who feel better to stay only in the organization for spending their careers. The good-valued things to be maintained by the foundation are the lecturers' happy feeling to spend careers in STIE, their reluctance to quit STIE, and their positively influencing loyalty.

Lastly, the lecturers' work discipline is also considered quite good. However, the lowest-valued things to be considered by the foundation are the inconsistency of sanction imposition for violating lecturers and the lecturers' lack of reluctance to commit violations.

\section{REFERENCES}

1. Adorni, E. Esharenona and Eruvwe Ufuoma. 2004. Staf discipline in Nigerian Universiy Libraries, Library Managemen, Vol.25.Iss 4 pp 223-229.

2. Allen, Natalie J and Meyer, John P. 1990. The Measurement and Antecedents of affective, continuance and normative commitment to the organization, Journal of Occupational Psychology, Vol 63. Pp $1-18$.

3. Azeem, Syed Mohammad. 2010. Job Satisfaction and Organizational Commitment among Employees in the Sultanate of Oman, Scientific Research, Vol 1. Pp $295-299$.

4. Chan, Sow Hup. 2006. Organizational identification and commitment of members of a human development organization, Journal of Management Development, Vol 25, Iss 3. Pp $249-268$.

5. Chang, Su-Chao dan Lee. Ming-Shing. 2006. Relationship among personality, JobCharacteristic, Job Satisfaction and Organizational Commitment - An Empirical Study in Taiwan, The Business Review, Cambridge, Vol 6, Iss 1. Pp $201-207$.

6. Chiun Lo, May and Ramayah, T. 2011. Mentoring and job satisfaction in Malaysian SMEs, Journal of Management Development, Vol 30, Iss 4. Pp $427-440$.

7. Darwish A. Yousef. 2000. Organizational commitment and job satisfaction as predictors of attitudes towards organizational change in a non-western setting, Personnel Review, Vol 29 Iss: 5 pp $567-592$.

8. Donna McNeese, Smith. 1996. Increasing Employee. Job Satisfcation and Organizational Commitment, Journal Of Healthcare Management Summers 41, No 2. pp 160 - 175.

9. English, Brian., Morrison, David., Chalon, Christhoper. 2010. Moderator effects of organizational tenure on the relationship between psychological climate and affective commitment, Journal of Management Development, Vol 29, Iss 4. pp 394 - 408.

10. FadillaHelmi, Avin. 1996. Disiplin Kerja, Buletin Psikologi, Tahun IV, Nomor 2.

11. Furnham, Adrian.,Eracleous, Andreas., Premuzic, Tomas Chamorro. 2009. Personality, motivation and job satisfaction: Hertzberg meets the Big Five, Journal of Managerial Psychology, Vol 24, Iss 8. pp $765-779$.

12. Gilder, Dick de. 2003. Commitment, trust and work behavior. The case of contingent workers, Personnel Review, Vol 32, No 5. pp 588 - 604.

13. Gouzali, Saydam. 2002. Manajemen Sumber Daya Manusia.Jakarta: PT. Gunung Agung

14. Gunlu, Ebru., Aksarayli, Mehmet., SahinPercin, Nilufer. 2010. Job satisfaction and organizational commitment of hotel managers in Turkey, International Journal of Contemporary Hospitality Management, Vol 22, Iss 5. pp $693-717$.

15. Haarr N, Robin. 1997. "They're making a bad name for department"' Exploring the link between organizational commitment and police occupational deviance in a police patrol bureau, Policing: An international Journal of Police Strategies \& Management, Vol 20, Iss: 4. pp $796-812$.

16. Handoko, Hani. 2010. ManajemenSumberDayaManusia. Yogyakarta: PenerbitAndi.

17. Henry, Simamora. 2005. ManajemenSumberDayaManusia.Yogyakarta: PenerbitAndi. 
18. Irawati, Dwi and Mustakim, Noor. Pengaruh Komitmen Organisasional, Disiplin Kerja dan Motivasi Kerja Terhadap Prestasi Kerja Pegawai Balai PelaksanaTeknis Bina Marga Wilayah Magelang.

19. James Boles, Ramana Madupalli, Brian Rutherford, John Andy Wood. 2007. The Relationship of Facets of Salesperson Job Satisfaction With Affective Organizational Commitment, Journal of Business \& Industrial Marketing, Vol 22, Iss 5. pp 311-321.

20. Jha, Sumi. 2011. Influence of psychological empowerment on affective, normative and continuance commitment: A study in the Indian IT industry, Journal of Indian Business Research, Vol 3, Iss 4. pp $263-282$.

21. Johan, Rita. 2002. Kepuasan Kerja Karyawan Dalam Lingkungan Institusi Pendidikan, Jurnal Pendidikan Penabur, No.01.

22. Lange, Thomas. 2008. Attitudes, attributes and institutions determining job satisfaction in Central and Eastern Europe, Employee Relations, Vol 31. No. 1. pp 81 - 97.

23. Lok, Peter dan Crawford, John. 1999. The relationship between commitment and organizational culture, subculture, leadership style and job satisfaction in organizational change and development, Leadership \& Organization Development Journal, Vol 20, Iss 7. pp $365-374$.

24. Maryadi. 2012. Pengaruh Budaya Organisasi, Kompensasi, dan Kepuasan KerjaTerhadap Disiplin Kerja Guru SD di Kecamatan Tengaran Kabupaten Semarang, JMP, Volume 1, Nomor 2, hal 177 - 188.

25. Meyer, John P., Stanley, David J., Herscovitch, Lynne, and Topolnytsky, Laryssa. 2002. Affective, Continuance, and Normative Commitment to the Organization: A Meta-analysis of Antencendents, Correlates, and Consequences, Journal of Vocational Behavior, Vol 6. Pp $20-52$.

26. Minnesota, Satisfaction Questionnaire. 1967. Vacational Psychology Research. University Of Minnesota.

27. Mottaz J, Clifford. 1988. Determinants of Organizational Commitment. Human Relations, Vol 41, Number 6. pp $467-482$.

28. Muhaimin. 2004. Hubungan Antara Kepuasan Kerja Dengan Disiplin Kerja Karyawan Operator Shawing Computer Bagian Produksi pada PT. Primarindo Asia InfrastrukturTbk di Bandung, Jurnal PSYCHE, Vol 1, No 1.

29. Naderi Anari, Nahid. 2012. Teachers: emotional intelligence, job satisfaction, and organizational commitment, Vol 24. Iss 4. pp $256-269$.

30. Nelson A, Silvia. 2012. Affective Commitment of generational cohorts of Brazilian nurses. Journal of Manpower, Vol 33, Iss 7. pp $804-821$.

31. Noor Arifin, Komaruddin. 2009. Analisis Pengaruh Kepemimpinan, Kapabilitas, Komitmen Terhadap Kinerja Anggota Satuan Komando Distrik Militer 0719 Jepara, Jurnal Dinamika Ekonomi \& Bisnis, Vol 6, No. 2. pp 171 - 186.

32. Prabu, Anwar. 2005. Pengaruh Motivasi Terhadap Kepuasan Kerja Pegawai Badan Koordinasi Keluarga Berencana Nasional Kabupaten Muara Enim, Jurnal Manajemen \& Bisnis Sriwijaya, Vol 3, No 6. Hal $1-25$.

33. Ridwan, Kuncoro Engkos Achmad. 2010. Cara Menggunakan dan Memaknai Analisis Jalur (Path Analysis). Cetakan Pertama. Bandung: Alfabeta.

34. Rollinson J, Derek. 2000. Supervisor and manager approaches to handling discipline and grievance: a follow - up study, Personal Review, Vol 29, Iss 6. pp 743 - 768.

35. Rowden W, Robert. 2000. The relationship between charismatic leadership behaviors and organizational commitment, Leadership \& Organization Development Journal, Vol 21, Iss 1. pp $30-35$.

36. Siagian, S. P. 2003. Manajemen Sumber Daya Manusia. Jakarta: BumiAksara Indonesia

37. Silva, Paula. 2006. Effects of Disposition on Hospitality employee job satisfaction and commitment, International Journal of Contemporary Hospitality Management, Vol 18, No 4. pp $317-328$.

38. Sopiah. 2008. Perilaku Organisasional. Yogyakarta: Penerbit Andi.

39. Sugiyono. 2010. Metode Penelitian Bisnis. Cetakan Kesebelas. Bandung: CV. Alfabeta. 
40. Sukirman. Hubungan Kepuasan Kerja dengan Disiplin Kerja Karyawan Bagian Produksi PT. Bintratex Semarang, ISSN: $1979-6889$.

41. Susilo, Martoyo. 2002. Manajemen Sumber Daya Manusia. Yogyakarta: BPFE.

42. Sutrisno, Edy. 2009. Manajemen Sumber Daya Manusia. Jakarta: Kencana.

43. Suyana Utama, Made. 2009. Aplikasi Analisis Kuantitatif. Denpasar: Sastra Utama.

44. Tranggono Probo, Rahadyan and Kartika, Andi. 2008. Pengaruh Komitmen Organisasional dan Profesional Terhadap Kepuasan Kerja Auditor dengan Motivasi Sebagai Variabel Intervening (Studi Empiris pada Kantor Akuntan Publik di Semarang), Jurnal Bisnis dan Ekonomi, Vol 15, No 1, ISSN: $1412-3126$. Hal $80-90$.

45. Wang, Xiaohui. 2007. Learning, job satisfaction and commitment: an empirical study of organizations in china, Vol 1, No 3. pp $167-179$.

46. Wei Amy Tian, Foreman. 2009. Job Satisfaction and Turnover in the Chinese Retail Industry, Chinese Management Studies, Vol 3, Iss 4. pp $356-378$.

47. Yiing, Lee Huey., Zaman Bin Ahmad, Kamarul. 2009. The Moderating Effect of Organizational Culture on The Relationship Between Leadership Behaviour and Organizational Commitment and Between Organizational Commitment and Job Satisfaction and Performance, Leadership \& Organization Development Journal, Vol 30, Iss 1 . pp $53-86$. 